Pendidikan Kimia Fakultas Keguruan dan Ilmu Pendidikan Universitas Mulawarman

http://jurnal.fkip.unmul.ac.id/index.php/bivalen

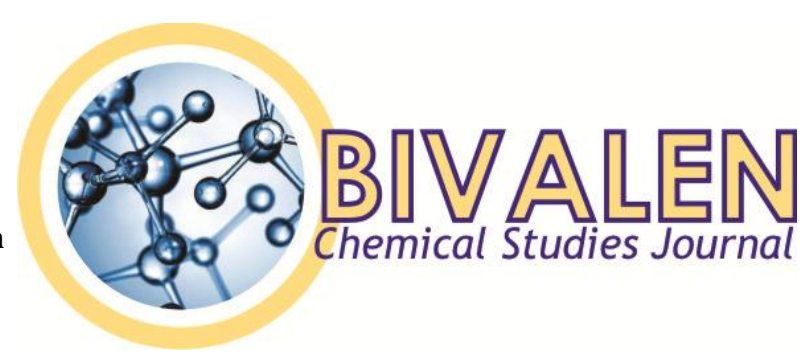

\title{
PERBEDAAN HASIL BELAJAR SISWA SMA PADA LABORATORIUM NYATA DAN VIRTUAL DENGAN MENGGUNAKAN MODEL PEMBELAJARAN INKUIRI TERBIMBING
}

\section{THE DIFFERENCE OF STUDENT LEARNING RESULT OF SENIOR HIGH SCHOOL OF REAL LABORATORY AND VIRTUAL BY USING THE GUIDED INQUIRY LEARNING MODEL}

\author{
Munik Endang Rizkiana*1, Mukhamad Nurhadi ${ }^{2}$, Maasje C. Watulingas ${ }^{1}$ \\ ${ }^{1}$ Program Studi Sarjana Pendidikan Kimia Fakultas Keguruan dan Ilmu Pendidikan. Universitas Mulawarman, \\ Samarinda, Kalimantan Timur, Indonesia \\ ${ }^{2}$ Program Studi Pascasarjana Pendidikan Kimia Fakultas Keguruan dan Ilmu Pendidikan. Universitas \\ Mulawarman, Samarinda, Kalimantan Timur, Indonesia \\ *Corresponding Author: munikrizkiana@yahoo.co.id(+6287545489625)
}

\begin{abstract}
ABSTRAK
Penelitian ini bertujuan untuk mengetahui perbedaan hasil belajar siswa SMA pada laboratorium nyata dan virtual dengan menggunakan model pembelajaran inkuiri terbimbing pada pokok bahasan larutan asam basa kelas XI IPA di SMA Negeri 11 Samarinda. Populasi pada penelitian ini adalah siswa kelas XI IPA di SMA Negeri 11 Samarinda sedangkan sampel pada penelitian ini adalah siswa kelas XI IPA-2 dan XI IPA-3 yang masing-masing kelas sebanyak 38 siswa dan penentuan sampel menggunakan purposive sampling. Teknik pengumpulan data pada penelitian ini dilakukan melalui post test sebanyak dua kali pertemuan pembelajaran dan satu kali pertemuan ulangan harian. Kontribusi nilai masingmasing post test adalah 30\% dan kontribusi nilai ulangan harian adalah 40\%. Berdasarkan hasil penelitian dan analisis data menunjukkan bahwa nilai rata-rata akhir siswa kelas XI IPA-2 dan XI IPA-3 sebesar 62,37 dan 85,13. Penelitian ini membuktikan bahwa terdapat perbedaan hasil belajar siswa SMA pada laboratorium nyata dan virtual dengan menggunakan model pembelajaran inkuiri terbimbing pada pokok bahasan larutan asam basa kelas XI IPA di SMA Negeri 11 Samarinda tahun ajaran 2016/2017.
\end{abstract}

Kata kunci : inkuiri terbimbing, laboratorium nyata, laboratorium virtual, hasil belajar

\section{ABSTRACT}

This study aims to determine the difference of students learning outcome in senior high school with real laboratory and virtual by using the guided inquiry learning model on acid-base solution subject in class XI IPA SMAN 11 Samarinda. The population were all of student class XI IPA at SMAN 11 Samarinda and the samples were student of class XI IPA 2 and XI IPA 3 which class are consisting 76 students with each class consist of 38 students and determination of samples using purposive sampling technique. Data collected was conducted twice learning meeting on daily test. The contribution value each meeting are $30 \%$ of post-test and the contribution value of daily test is $40 \%$. Based on the research and data analysis showed that the average of value on class XI IPA-2 and XI IPA-3 are 62.37 and 85.13. This study proved that there are difference of student learning outcome senior high school with real laboratory and virtual by using the guided inquiry learning model on the subject acid-base solution class XI IPA in SMA Negeri 11 Samarinda 2016/2017.

Keywords: guided inquiry, real laboratory, virtual laboratory, learning result 


\section{PENDAHULUAN}

Keberhasilan siswa dalam menguasai suatu materi pelajaran dipengaruhi oleh cara dan upaya dalam pembelajaran siswa. selain tergantung dari kemampuan dasar yang dimiliki siswa tentang pelajaran dan upaya siswa tersebut dalam belajar Hasil belajar merupakan indikator keberhasilan seseorang dalam usaha menyampaikan materi pelajaran untuk siswa (Slameto. 2003). Pemilihan model pembelajaran harus sesuai dengan materi yang disampaikan. Model pembelajaran inkuiri dirancang untuk mengajak siswa secara langsung ke dalam proses ilmiah dalam waktu yang relatif singkat yang bermula dari merumuskan masalah, merumuskan hipotesis, mengumpulkan data, menganalisis data, dan membuat kesimpulan (Gulo, 2008).

Beberapa peneliti telah melakukan penelitian mengenai hasil belajar siswa dengan menggunakan laboratorium nyata dan virtual. Artha (2009) mengungkapkan bahwa hasil belajar siswa pada laboratorium nyata lebih tinggi daripada laboratorium virtual. Menurut penelitian yang telah dilakukan oleh Riana (2011), hasil belajar siswa yang diajarkan dengan menggunakan laboratorium virtual memiliki hasil belajar yang lebih baik daripada hasil belajar siswa yang diajar dengan menggunakan laboratorium nyata. Hal ini karena pada laboratorium virtual lebih memberikan rasa aman, rendahnya resiko bahaya selama praktikum, ketersediaan alat dan bahan yang tak pernah habis/rusak, serta kemudahan dan efisiensi waktu pelaksanaan praktikum sehingga percobaan dapat dilakukan berulang.

\section{METODE PENELITIAN}

Penelitian ini dilaksanakan di SMA Negeri 11
Samarinda yang bertempat di Jalan Sultan Sulaiman Pelita IV, Kelurahan Sambutan, Kecamatan Sambutan, Samarinda. Populasi dalam penelitian ini adalah seluruh peserta didik kelas XI IPA SMAN 11 Samarinda. Sampel dalam penelitian ini yaitu kelas XI IPA-2 dan XI IPA-3 yang berjumlah 76 siswa dengan masing-masing kelas sebanyak 38 siswa dan penentuan sampel menggunakan purposive sampling. Model pembelajaran yang digunakan dalam penelitian ini adalah model pembelajaran inkuiri terbimbing. Kelas XI IPA-2 merupakan kelas yang menggunakan model pembelajaran inkuiri terbimbing dengan metode laboratorium nyata dan kelas XI IPA 3 merupakan kelas yang menggunakan model pembelajaran inkuiri terbimbing dengan metode laboratorium virtual. Pokok bahasan yang digunakan pada penelitian ini adalah materi indikator asam basa. Teknik pengumpulan data dalam penelitian ini adalah menggunakan teknik tes berupa tes tertulis dengan bentuk soal pilihan ganda. Tes tertulis pada penelitian ini berupa soal post test tiap kali pertemuan dan ulangan harian. Total nilai akhir hasil belajar siswa diperoleh dari masingmasing post test dengan persentase $30 \%$ dan nilai ulangan harian dengan persentase $40 \%$. Hasil Belajar siswa dianalisis dengan menggunakan uji $\mathrm{F}$ dan uji t. Hasil uji t yang diperoleh kemudian digunakan untuk menguji hipotesis dengan membandingkan nilai $t_{\text {hitung }}$ dengan $t_{\text {tabel }}$ pada taraf signifikan 5\% (Pramudjono, 2011).

\section{HASIL DAN PEMBAHASAN}

Data hasil belajar siswa kelas XI IPA-2 yang menggunakan model pembelajaran inkuiri terbimbing dengan metode laboratorium nyata sebelum dan sesudah perlakuan dapat dilihat pada Tabel 1.

Tabel 1

Data hasil belajar siswa

\section{Nilai}

\begin{tabular}{cccccc} 
Kelas & Sebelum & \multicolumn{4}{c}{ Sesudah perlakuan } \\
& perlakuan & Post & Post & Ulangan & Hasil \\
& Test 1 & Test 2 & Harian & Belajar \\
\hline $\begin{array}{c}\text { XI IPA-2 (Laboratorium } \\
\text { nyata) }\end{array}$ & 83,95 & 80,79 & 48,68 & 60 & $62,37^{*}$ \\
$\begin{array}{c}\text { XI IPA-3 (Laboratorium } \\
\text { virtual) }\end{array}$ & 84,60 & 90,26 & 91,84 & 79,21 & 85,13 \\
\hline
\end{tabular}

"Berbeda $(\alpha=5 \%)$ berbeda dengan kelas laboratorium virtual pada kolom yang sama 
Data hasil penelitian berdasarkan Tabel nilai hasil belajar siswa kelas XI IPA-2 yang mengenakan model pembelajaran inkuiri terbimbing dengan metode laboratorium nyata sebelum perlakuan diperoleh nilai rata-rata hasil belajar sebesar 83,95 dan sesudah perlakuan diperoleh nilai rata-rata hasil belajar sebesar 62,37. Data hasil penelitian nilai XI IPA-3 yang menggunakan model pembelajaran inkuiri terbimbing dengan metode laboratorium virtual sebelum perlakuan diperoleh hasil sebesar 84,60 dan sesudah perlakuan diperoleh hasil sebesar 85,13. Hasil belajar kelas XI IPA-3 yang menggunakan model pembelajaran inkuiri terbimbing dengan laboratorium virtual lebih tinggi dari pada kelas XI IPA-2 yang menggunakan laboratorium nyata.

Penggunaan laboratorium virtual memberikan kesempatan bagi siswa untuk melakukan praktikum secara mandiri sesuai prosedur kerja. Siswa bebas menggunakan alat dan bahan laboratorium secara virtual tanpa ada rasa takut salah dan dapat mengembangkan ide baru untuk melakukan percobaan. Menurut Ariani dan Haryanto (2010), laboratorium virtual sangat bermanfaat ketika eksperimen riil tidak mungkin dilakukan atau terlalu mahal dan berbahaya untuk dilaksanakan. Laboratorium virtual memungkinkan siswa melakukan praktikum atau eksperimen sekolah menghadapi situasi praktikum dan menggunakan peralatan pada laboratorium nyata. Menurut Farreira dalam Mayasita (2013), berikut manfaat yang diperoleh dari penggunaan laboratorium virtual yaitu mengurangi keterbatasan waktu (efisien), jika tidak cukup waktu untuk menginformasikan prosedur praktikum kepada siswa hingga mereka paham; ekonomis, tidak membutuhkan bangunan laboratorium, alat dan bahan seperti pada laboratorium nyata; meningkatkan kualitas eksperimen, karena eksperimen dapat diulang untuk memperjelas keraguan siswa; meningkatkan keamanan dan keselamatan, karena tidak berinteraksi dengan alat dan bahan kimia yang nyata. Penggunaan laboratorium virtual sebagai media pembelajaran memiliki banyak manfaat, namun penggunaan laboratorium virtual juga memiliki beberapa kelemahan yaitu siswa sebagai pengguna tidak dapat melatih kemampuan psikomotorik dalam menggunakan peralatan pada laboratorium nyata. Laboratorium virtual tidak memberikan pengalaman langsung secara nyata karena kurangnya pengalaman pada laboratorium yang sebenarnya. Selain itu, pengguna tidak dapat mengembangkan sikap ilmiah seperti ketelitian, kejujuran, tanggung jawab, dan terbuka. Oleh karena itu agar siswa dapat melatih kemampuan psikomotorik, setelah menggunakan laboratorium virtual sebagai media pembelajaran harus melakukan praktikum yang sebenarnya di laboratorium nyata.

Menurut Sutikno (2014), praktikum merupakan kegiatan pembelajaran yang memberikan kesempatan kepada siswa melakukan percobaan untuk membuktikan sendiri hipotesis atau konsep yang telah dipelajari dengan mengamati proses dan hasil percobaan. Pada prinsipnya praktikum merupakan serangkaian percobaan yang dilakukan eksperimen di dalam laboratorium atau ruangan tertentu. Sedangkan menurut Amien (1988), praktikum ialah kegiatan di laboratorium yang dilaksanakan oleh praktikan dengan atau tanpa himbingan dosen/asisten. Kegiatan praktikum dilakukan siswa setelah guru memberikan arahan untuk melakukan percobaan. Dengan adanya kegiatan praktikum siswa dapat melakukan percobaan untuk membuktikan sebuah teori dari konsep yang telah dipelajari, mengumpulkan data, dan menemukan sendiri jawaban dari masalah yang dihadapi secara nyata melalui metode ilmiah. Selain itu praktikum dapat meningkatkan pemahaman siswa terhadap materi yang sedang atau telah dipelajari dan melatih keterampilan psikomotorik siswa agar terampil menggunakan alat laboratorium. Menurut Faizi (2013), penggunaan metode praktikum memiliki beberapa kelebihan dan kekurangan. Berikut beberapa kelebihan dari penggunaan metode praktikum, yaitu siswa lebih percaya diri atas kesimpulan berdasarkan percobaan yang dilakukan, memotivasi siswa untuk mengeksplorasi dan mengembangkan penemuan dari hasil percobaan yang telah dilakukan, hasil percobaan yang telah dilakukan dapat bermanfaat bagi kehidupan makhluk hidup. Selain memiliki beberapa kelebihan penggunaan metode praktikum juga memiliki beberapa kekurangan yaitu memerlukan berbagai fasilitas peralatan dan bahan yang tidak selalu mudah diperoleh dan kadang kala mahal, metode ini menuntut ketelitian, keuletan, dan kesabaran peneliti setiap percobaan tidak selalu memberikan hasil yang diharapkan, karena terdapat faktor yang menghambat . 
Pada laboratorium virtual simulasi praktikum menggunakan komputer dapat menjadi tempat melakukan eksperimen yang bersifat abstrak yang memperlihatkan ukuran atom-atom yang tidak terlihat mata ketika dilakukan percobaan di laboratorium kimia. Belajar dengan komputer menggunakan simulasi menjadikan pembelajaran menjadi menarik minat siswa sehingga siswa menjadi lebih menyukai pelajaran kimia materi asam basa. Sebagaimana penelitian Wuryaningsih dan Sukirno (2014), dengan menggunakan model pembelajaran fisika berbasis teknologi menggunakan media simulasi PhET siswa lebih menikmati pembelajaran dan hasilnya menunjukkan adanya peningkatan yang cukup baik. Proses pembelajaran dengan media komputer merupakan pembelajaran yang menyenangkan, dengan siswa menyukainya akan menjadikan siswa meluangkan waktu lebih banyak untuk belajar lebih rajin serta membangun suatu pikiran dalam dirinya akan rasa butuh untuk mempelajari pelajaran kimia. Kebutuhan tersebut membawa siswa untuk mengikuti pembelajaran dengan baik sehingga dapat mencapai tujuan dalam pembelajaran. Penyampaian pembelajaran dengan simulasi lebih efektif dan menarik menjadikan siswa menjadi lebih mudah memahami akan pelajaran kimia.Sebagaimana Tuysuz (2010), dalam penelitiannya menyatakan bahwa pembelajaran dengan laboratorium virtual lebih efektif daripada laboratorium nyata. Selanjutnya Finkelstein dkk. (2004), dalam penelitiannya menyimpulkan bahwa mahasiswa yang belajar dengan simulasi PHET dapat menerangkan bagaimana kerja sirkuit listrik yang sebenarnya sehingga dapat memiliki pemahaman yang paling unggul secara konseptual daripada kelompok laboratorium nyata dan kelompok yang tidak belajar dengan percobaan.

Pada saat pembelajaran, terlihat siswa pada kelas laboratorium virtual lebih fokus dalam belajar, baik dalam mendengarkan arahan dan instruksi guru saat melakukan percobaan melalui simulasi. Siswa juga terlihat tekun dalam melaksanakan percobaan, tidak ada yang berjalan-jalan di dalam maupun keluar ruangan. Belajar dengan menggunakan media komputer menjadi salah satu daya tarik siswa dalam mengikuti pelajaran sesuai pendapat Sudjana dan Rivai (2005), media pembelajaran yang berbasis komputer merupakan salah satu media yang dapat digunakan untuk memperoleh pembelajaran yang lebih menarik. Penelitian yang dilakukan oleh Pratiwi dkk. (2014), menunjukkan bahwa pengembangan media pembelajaran berupa LKS dengan menggunakan virtual laboratorium layak digunakan sebagai media pembelajaran yang menunjukkan kualitas media yang menarik, efektif dan sangat mudah digunakan serta bermanfaat untuk meningkatkan hasil belajar. Selanjutnya Perkins dkk (2012), dalam penelitiannya menyimpulkan bahwa pembelajaran dengan simulasi PhET menjadikan pembelajaran yang efektif.

Hal ini terjadi karena pembelajaran dengan simulasi melalui komputer merupakan media berbasis visual yang dapat membuat fenomena dalam kehidupan nyata ke dalam simulasi dalam bentuk atom-atom yang berikatan sehingga dapat membangkitkan minat peserta didik untuk belajar. Perkins dkk. (2006), menyatakan pembelajaran dengan menggunakan simulasi PhET dapat dengan mudah dijalankan dan interaktif yang membawa peserta didik dalam pembelajaran yang lebih menyenangkan. Sesuai pernyataan Arsyad (2011), media visual dapat menumbuhkan minat peserta didik sehingga dapat menghubungkan antara isi materi dengan dunia nyata. Sebagaimana penelitian yang dilakukan oleh McKagan dkk. (2008), simulasi PhET sangat interaktif dan efisien sehingga peserta didik lebih fokus pada konsep, serta efektif sehingga mudah digunakan oleh peserta didik sehingga proses pembelajaran menjadi lebih menarik.

Peserta didik yang belajar dengan simulasi lebih fokus dengan percobaan sehingga menciptakan kelas yang tenang dan disiplin. Hal ini terjadi karena peserta didik belajar dalam suasana yang menyenangkan. Pembelajaran dengan simulasi dapat mewujudkan suasana kelas yang nyaman, di mana peserta didik belum pernah diajak untuk belajar dengan menggunakan media komputer di sekolah sehingga selain menjadi hal yang baru dalam melakukan percobaan, belajar dengan simulasi juga mudah dilakukan, sehingga peserta didik lebih berpartisipasi dalam pembelajaran. Rohani (2004), memaparkan bahwa salah satu hal yang bisa dilakukan oleh guru dalam pembelajaran untuk dapat meningkatkan motivasi belajar dengan mewujudkan suasana kelas yang menggembirakan dan menyenangkan sehingga mendorong partisipasi peserta didik untuk terlibat dalam pembelajaran. Selanjutnya Munir (2012), berpendapat bahwa pembelajaran dengan media simulasi PhET dapat mewujudkan suasana kelas yang menyenangkan karena peserta didik dapa mengembangkan kreatifitas ya unuk melakukan percobaan yang akan berbahaya jika dilakukan dalam laboratorium kimia. 
Selanjutnya Fenrich (1997), memuparkan pembelajaran dengan media komputer dapat memberikan pengalaman baru yang menyenangkan dan menumbuhkan inspirasi, baik bagi pendidik maupun peserta didik sehingga dapat meningkatkan motivasi belajar.

Pada simulasi siswa dapat dengan leluasa melakukan praktikum tanpa harus merasa khawatir dengan ketelitian tinggi dalam menangani alat dan bahan-bahan yang berbahaya serta beresiko terhadap kecelakaan kerja sebagaimana di laboratorium kimia, sehingga dengan simulasi siswa dapat benarbenar menikmati bekerja dengan perlakuan pada komputer. Siswa juga dapat mengulangi percobaannya di rumah maupun di sekolah pada waktu yang lain. Sebagaimana penelitian yang dilakukan oleh Singh (2013), menyimpulkan bahwa pembelajaran dengan virtual learning environment dapat dilakukan tanpa batas waktu dan ruang, dapat diterapkan pada materi yang rumit, serta dapat meningkatkan pemahaman peserta didik menjadi lebih baik.

Kesimpulan didukung dengan uji statistik yang membuktikan bahwa terdapat perbedaan hasil belajar siswa yang menggunakan laboratorium nyata dan virtual dalam model pembelajaran inkuiri terbimbing. Pembelajaran yang menggunakan laboratorium virtual nilai rata-ratanya lebih bagus daripada pembelajaran yang menggunakan laboratorium nyata.

\section{SIMPULAN}

Berdasarkan hasil penelitian dan analisis data yang telah dilakukan dapat disimpulkan bahwa terdapat perbedaan hasil belajar siswa yang menggunakan laboratorium nyata dan virtual dalam model pembelajaran inkuiri terbimbing pada pokok bahasan larutan asam basa kelas XI di SMA Negeri 11 Samarinda.

\section{UCAPAN TERIMAKASIH}

Ucapan terima kasih dan penghargaan yang setinggi-tingginya atas kerja samanya kepada SMA Negeri 11 Samarinda yang telah mengizinkan penulis melaksanakan penelitian.

\section{DAFTAR PUSTAKA}

Ahmad Rohani. (2004). Pengelolaan Pengajaran. Jakarta: PT Rineka Cipta.

Amien, Mohammad (1988). Melakukan Pembelajaran IPA dengan Menggunakan Model Pembelajaran Discovery dan Inquiry. Jakarta.
Anam, Khoirul. (2015). Pembelajaran berbasis inkuiri (metode dan aplikasi). Yogyakarta: Pustaka Pelajar.

Ariani, Niken \& Dany Haryanto. (2010). Pembelajaran Multimedia di Sekolah. Jakarta: Prestasi Pustaka Publisher.

Arsyad, A. (2011). Media Pembelajaran. Jakarta: PT Raja Grafindo Persada

Artha, A. (2009). Pembelajaran IPA dengan inkuiri bebas termodifikasi menggunakan lab nyata dan lab virtual ditinjau dari kemampuan berpikir dan gaya belajar siswa pada SMP Negeri 5 Yogyakarta. Jurnal Inkuiri. 1(2), 105-111.

Faizi, M. (2013). Ragam Metode Mengajarkan Eksakta pada Murid. Jogjakarta: DIVA Press.

Ferreira, MIM. (2010), Intelligent classrooms and smart software: Teaching and learning in today's University. Springer Science and Business Media. Springer publications.

Fenrich, P. (1997). Practical Guidelines For Creating Instructional Multimedia Applications. Fort Worth: The Dryden Press.

Finkelstein, N., W. Adams, C. Keller, K. Perkins \& C. Wieman. (2004). High-Tech tools for teaching physics The physics education technology project. MERLOT Journal of Online Learning and Teaching. 2(3):110-121.

Gulo, W. (2008). Strategi belajar mengajar. Jakarta: Grasindo.

Mckagan, S. B., K. K. Perkins, M. Dobson, C. Malley, S. Reid, R. LeMaster, and C. E. Wieman. (2008). Developing and Researching PhET simulations for Teaching Quantum Mechanics. American Journal of Physics. http://www.colorado.edu/physics Educationlssu es/papers. 1-13,

Munir, M. I. T. (2012). Multimedia Konsep dan Aplikasi dalam Pendidikan. Bandung: Alfabeta.

Singh, G. K. (2013). Virtual learning environment for next generation in clectronics and telecommunications courses. International Journal of Technological Exploration and Learning (IJTEL), 2(5): 2319-2135.

Perkins, K., W. Adams, M. Dubson, N. Finkelstein, S. Reid and C. Wieman. (2006). Phet: Interactive simulations for teaching and learning physics. The Physics Teacher, Vol 44: 18-23. Perkins dkk.

Pramudjono. (2011). Statistika dasar (aplikasi untuk penelitian). Samarinda: Purry Kencana Mandiri

Pratiwi, G. C. M., E. Suyanto dan I. Wahyudi. (2014). Pengembangan suplemen pembelajaran fisika gelombang elektromagnetik cahaya 
Bivalen: Chemical Studies Journal, 2018, Vol. 1, No. 1

sebagai partikel memanfaatkan virtual laboratorium. Jurnal Pembelajaran Fisika, 2(4):1-12.

Riana. (2011). Pembelajaran kimia dengan metode inkuiri terbimbing antara penggunaan lab virtual dan lab nyata ditinjau dari gaya belajar dan aktivitas belajar siswa pada SMA Batik 2 Surakarta pada materi koloid TP. 2009/2010. Thesis. Surakarta: Universitas Sebelas Maret.

Slameto. (2003). Belajar dan faktor vang mempengaruhinya. Jakarta: PT. Rineka Cipta

Sudjana. N dan Rivai, A. (2005). Media Pengajaran. Bandung : Sinar Baru.

Sutikno, Sobry,. (2014). Metode dan Model-model Pembelajaran. Lombok: Holistica.

Tuysuz, C. (2010). The effect of the virtual laboratory on students' achievement and attitude in chemistry. International Online Journal of Educational Sciences, 2(1):37-53.

Wuryaningsih, R. dan Suhamo. (2014). Penerapan Pembelajaran Fisika dengan Media Simulasi PhET pada Pokok Bahasan Gaya untuk Meningkatkan Hasil Belajar Peserta didik Kelas VII A SMPN 6 Yogyakarta. Prosiding Pertemuan Ilmiah XXVIII HFI Jateng dan DIY, Yogyakarta. 26 April 2014. 